Article

\title{
Effect of Novel Penicillium verruculosum Enzyme Preparations on the Saccharification of Acid- and Alkali-Pretreated Agro-Industrial Residues
}

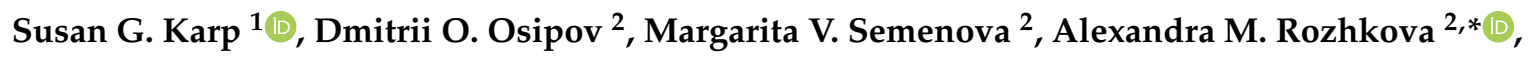 \\ Ivan N. Zorov ${ }^{2,3}$, Olga A. Sinitsyna ${ }^{3}$, Carlos R. Soccol ${ }^{1}$ and Arkady P. Sinitsyn ${ }^{2,3}$ \\ 1 Department of Bioprocess Engineering and Biotechnology, Federal University of Paraná, \\ Curitiba 81531-990, Paraná, Brazil; susan.karp@ufpr.br (S.G.K.); soccol@ufpr.br (C.R.S.) \\ 2 Federal Research Centre Fundamentals of Biotechnology of the Russian Academy of Sciences, \\ 119071 Moscow, Russia; doosipov@gmail.com (D.O.O.); margs@mail.ru (M.V.S.); inzorov@mail.ru (I.N.Z.); \\ apsinitsyn@gmail.com (A.P.S.) \\ 3 Department of Chemistry, Lomonosov Moscow State University, 119991 Moscow, Russia; \\ oasinitsyna@gmail.com \\ * Correspondence: a.rojkova@fbras.ru
}

Received: 18 August 2020; Accepted: 4 September 2020; Published: 7 September 2020

\begin{abstract}
This study aimed at evaluating different enzyme combinations in the saccharification of sugarcane bagasse (SCB), soybean husks (SBH) and oil palm empty fruit bunches (EFB) submitted to mild acid and alkaline pretreatments. Enzyme pools were represented by B1 host (crude cellulase/xylanase complexes of Penicillium verruculosum); B1-XylA (Penicillium canescens xylanase A expressed in P. verruculosum B1 host strain); and F10 (Aspergillus niger $\beta$-glucosidase expressed in B1 host strain). Enzyme loading was $10 \mathrm{mg}$ protein/g dry substrate and $40 \mathrm{U} / \mathrm{g}$ of $\beta$-glucosidase (F10) activity. SCB was efficiently hydrolyzed by B1 host after alkaline pretreatment, yielding glucose and reducing sugars at $71 \mathrm{~g} / \mathrm{L}$ or $65 \mathrm{~g} / 100 \mathrm{~g}$ of dry pretreated substrate and $91 \mathrm{~g} / \mathrm{L}$ or $83 \mathrm{~g} / 100 \mathrm{~g}$, respectively. B1 host performed better also for $\mathrm{EFB}$, regardless of the pretreatment method, but yields were lower (glucose 27-30 g/L, 25-27 g/100 g; reducing sugars 37-42 g/L, 34-38 g/100 g). SBH was efficiently saccharified by the combination of B1 host and B1-XylA, yielding similar concentrations of reducing sugars for both pretreatments $(92-96 \mathrm{~g} / \mathrm{L}, 84-87 \mathrm{~g} / 100 \mathrm{~g})$; glucose recovery, however, was higher with alkaline pretreatment $(81 \mathrm{~g} / \mathrm{L}, 74 \mathrm{~g} / 100 \mathrm{~g})$. Glucose and reducing sugar yields from initial substrate mass were $42 \%$ and $54 \%$ for SCB, $36 \%$ and $42-47 \%$ for SBH and $16-18 \%$ and $21-26 \%$ for EFB, respectively.
\end{abstract}

Keywords: sugarcane bagasse; soybean husks; palm empty fruit bunches; recombinant enzymes; pretreatment

\section{Introduction}

Agro-industrial residues are important sources of lignocellulosic biomass, the main feedstock to be used as a substitute for petrol in a circular bioeconomy. These organic materials are generated in large volumes as a result of agricultural and agro-industrial activities and are in great part subtilized, especially in developing countries that are the main suppliers of commodities. According to Magalhães Jr. et al. [1], around 900 million tons of biomass from agro-industrial residues such as sugarcane bagasse, cereal straws and oil palm solid wastes will be generated in South America in 2025, and their most probable destination, if not left in the field, is burning for energy generation and composting, the most traditional processing methods. However, considering that more than $60 \%$ of their mass can be converted to fermentable sugars, these residues could be valorized through microbial processes 
to produce second generation $(2 \mathrm{G})$ ethanol and other biofuels, organic acids, biomaterials and many other commercial bioproducts.

Nowadays, $2 \mathrm{G}$ ethanol is the product with the most mature stage of technological development obtained in lignocellulose biorefineries. However, the cost of $2 \mathrm{G}$ ethanol is still not competitive with that of petroleum-based liquid fuels [2], in part because of the cost of enzymes that are necessary to convert fibrous carbohydrates into fermentable sugars. Another step that impacts the overall cost and lacks technological maturity is the pretreatment, necessary to prepare the recalcitrant structure of lignocellulosic biomass to enzymatic hydrolysis or saccharification. In general, the aim of the pretreatment is to enhance the recovery of glucose and other reducing sugars from lignocellulosic biomass in the saccharification step, and this is usually accomplished through the decrease of the crystallinity of cellulose, degree of polymerization, lignin content and moisture content, associated to an increase of available surface area [3].

Several methods have been reported to pretreat lignocellulosic biomass, most of them thermochemical processes. These include steam explosion with or without alkali washing, dilute acid hydrolysis, alkaline pretreatment, organosolv, ammonia fiber expansion, liquid hot water, wet oxidation and others [3]. Alkaline pretreatment is especially efficient in solubilizing lignin, while mild acid pretreatment is more directed to the hemicellulose fraction.

In 2018, the global sugarcane production was of 1.9 billion tons, and Brazil was the main producer accounting for $39 \%$ of the total production, followed by India with 20\% [4]. In the harvest of 2018/2019, India has surpassed Brazil producing more than 700 million tons, but for 2019/2020 the projections are very similar for both countries [5]. The Brazilian production estimative for the harvest of 2019/2020 is of around 643 million tons [6]. Sugarcane bagasse is a porous residue of cane stalks generated after the crushing and extraction of sugarcane juice. It is composed mainly by cellulose (32-44\%), hemicellulose (27-32\%), lignin (19-24\%) and ashes (4.5-9\%). Sugar mills generate approximately $270-280 \mathrm{~kg}$ of bagasse (with $50 \%$ moisture) per metric ton of sugarcane $[7,8]$.

Soybean is one of the most important sources of vegetable protein for human and animal nutrition and one of the most economical sources of oil for food and biofuel production. According to the United States Department of Agriculture [9], the world production of soybean for 2019/2020 is estimated at 338 million metric tons. The world's leading producer is Brazil and the second is the United States, responsible for $37 \%$ and $27 \%$ of the global production, respectively. From one ton of soybean with around $13 \%$ moisture, $50 \mathrm{~kg}$ of soybean husks are obtained [10]. The composition of soybean husks depends on the dehulling process, so they may contain varying amounts of cellulose $(29-51 \%)$, hemicelluloses (10-25\%), lignin (1-4\%), pectins (4-8\%), proteins (11-15\%) and minor extractives [11].

The global production of oil palm is estimated at 73 million metric tons for the period of 2019/2020, Indonesia and Malaysia being the leading producers with $58 \%$ and $26 \%$ of the total, respectively [9]. The milling of oil palm to extract the oil generates a solid fibrous residue, named oil palm empty fruit bunches (EFB). It is estimated that for each ton of fresh fruit bunches processed, $220 \mathrm{~kg}$ of EFB are generated. This residue is composed of around 30, 25 and 25\% (mass percentages) of cellulose, hemicellulose and lignin, respectively [12].

The present work aimed at evaluating the effect of different enzyme preparations and combinations in the saccharification of these three important agro-industrial residues, the sugarcane bagasse, soybean husks and oil palm empty fruit bunches, pretreated by mild acid and alkali. The enzyme pools were represented by cellulase and xylanase complexes of Penicillium verruculosum (B1 host preparation), by the B1-XylA preparation obtained through the recombinant expression of Penicillium canescens xylanase A in the P. verruculosum B1 host strain, and by the F10 preparation obtained by recombinant expression of Aspergillus niger $\beta$-glucosidase in the B1 host strain. All preparations were crude, which could significantly reduce the cost associated to the enzymatic saccharification step. 


\section{Materials and Methods}

\subsection{Substrates}

Sugarcane bagasse (SCB) was donated by the Usina Santa Terezinha (Maringá, Paraná, Brazil), soybean husks (SBH) were purchased from the company Imcopa (Araucária, Paraná, Brazil) and oil palm empty fruit bunches (EFB) were provided by the company Biopalma Vale S.A. (Mojú, Pará, Brazil). Substrates were dried at $70^{\circ} \mathrm{C}$ overnight, grinded in a knife mill and particle sizes $<3 \mathrm{~mm}$ were selected by sieving. SCB and EFB presented a small fibers aspect and SBH presented a powder aspect. Table 1 presents the composition of each substrate.

Table 1. Substrates' composition (\% in dry basis).

\begin{tabular}{cccc}
\hline Substrate & SCB & SBH & EFB \\
\hline Cellulose & 36 & 37 & 28 \\
Hemicellulose & 31 & 27 & 24 \\
Lignin & 23 & 8.7 & 20 \\
Lipids & 2.3 & 1.9 & 6.3 \\
Proteins & 2.2 & 14 & 3.4 \\
Ash & 2.7 & 4.2 & 3.2 \\
Extractives/others & 2.2 & 6.8 & 15
\end{tabular}

SCB — sugarcane bagasse; SBH—soybean husks; EFB_empty fruit bunches of oil palm. Analytical methods were: NREL TP-510-42618 (cellulose, hemicellulose, lignin, others-pectin and acetyl); gravimetric analysis after solvent extraction in Soxhlet using hexane (lipids); Kjeldahl (proteins); gravimetric analysis after calcination at $555{ }^{\circ} \mathrm{C}$ for $6 \mathrm{~h}$ (ash); NREL TP-510-42619 (extractives); “others” are mostly represented by pectin in SBH and acetyl in EFB.

\subsection{Enzyme Preparations}

Three different enzyme preparations (Table 2) were used in this study in different combinations. Dry B1 host preparation represents a complex of cellulases and xylanases obtained by highly productive recombinant $P$. verruculosum strain after UV-mutagenesis [13,14]; dry B1-XylA preparation was obtained by recombinant $P$. verruculosum strain after heterologous expression of $P$. canescens xylanase A [15]; and dry F10 preparation was obtained by recombinant $P$. verruculosum strain after heterologous expression of Aspergillus niger $\beta$-glucosidase (cellobiase) [16].

Table 2. Enzyme preparations.

\begin{tabular}{cccccc}
\hline Name & Protein, $\mathbf{m g} / \mathbf{g}$ & CMC, U/g & $\beta$-Glucan, U/g & Xylan, U/g & pNPG, U/g \\
\hline B1 host & 970 & 16,542 & 15,062 & 17,532 & 1074 \\
B1-XylA & 441 & 2240 & 2240 & 60,000 & 610 \\
F10 & 655 & 7007 & 6797 & 3800 & 39,852 \\
\hline
\end{tabular}

Activities of enzyme preparations (Table 2) toward carboxymethylcellulose (CMC), barley $\beta$-glucan and birch wood xylan were determined by detection of reducing sugars release using Somogyi-Nelson assay [17-19]. Enzyme activities were assayed for $10 \mathrm{~min}$ at $\mathrm{pH} 5$ (0.05 M Na-acetate buffer) and $50{ }^{\circ} \mathrm{C}$ using a substrate concentration of $0.5 \%$ in the reaction mixture [20]. CMCase, $\beta$-glucanase and xylanase activities were expressed in international units. One unit of activity corresponds to the quantity of enzyme releasing $1 \mu \mathrm{mol}$ of reducing sugars (in glucose equivalents) per minute.

Enzyme activity toward $p$-nitrophenyl glucopyranoside (pNPG) was determined by detection of $p$-nitrophenyl release by a photometric assay. Enzyme activity was assayed for $10 \mathrm{~min}$ at $\mathrm{pH} 5$ (0.05 M Na-acetate buffer) and $40{ }^{\circ} \mathrm{C}$ using a substrate concentration of $10 \mathrm{mM}$ in the reaction mixture. One $\beta$-glucosidase unit of activity is the amount of enzyme which liberates $1 \mu \mathrm{mol}$ of $p$-nitrophenol per minute [21]. 


\subsection{Pretreatment Conditions}

Alkaline pretreatment was conducted with a substrate concentration of $10 \%(\mathrm{~m} / \mathrm{v})$ of solids, $\mathrm{NaOH}$ $2 \%(\mathrm{~m} / \mathrm{v})$, at $121{ }^{\circ} \mathrm{C}$ for $1 \mathrm{~h}$. After, the $\mathrm{pH}$ of the reaction medium was adjusted to 4.5 with $\mathrm{HCl}$, the solids were separated from the liquid phase in a glass filter and washed abundantly with distilled water. The excess water was removed, and a sample was taken to determine the moisture content of the pretreated substrates by gravimetric analysis.

Acid pretreatment was conducted with a substrate concentration of $10 \%(\mathrm{~m} / \mathrm{v})$ of solids, $\mathrm{H}_{2} \mathrm{SO}_{4}$ $1 \%(\mathrm{~m} / \mathrm{v})$, at $121^{\circ} \mathrm{C}$ for $1 \mathrm{~h}$. Afterward, the $\mathrm{pH}$ of the reaction medium was adjusted to 4.5 with $\mathrm{NaOH}$, and the solids were separated from the liquid phase in a glass filter and washed abundantly with distilled water. The excess water was removed, and a sample was taken to determine the moisture content of the pretreated substrates by gravimetric analysis.

\subsection{Saccharification Conditions}

Three different combinations of enzyme preparations were tested, as presented in Table 3. Substrate concentration (in dry basis) was set at $100 \mathrm{~g} / \mathrm{L}$, in sodium acetate buffer (1 M, pH 4.5), and the reaction volume was $20 \mathrm{~mL}$. The enzyme dosage for B1 host, B1-XylA and B1 host + B1-XylA was $10 \mathrm{mg}$ protein/g dry substrate. In all cases, F10 $\beta$-glucosidase preparation was added to the reaction mixture in the dosage $40 \mathrm{U}$ of pNPG /g of dry substrate. Hydrolysis flasks were incubated at $45^{\circ} \mathrm{C}, 250 \mathrm{rpm}$ and samples were taken after $3 \mathrm{~h}, 24 \mathrm{~h}$ and $48 \mathrm{~h}$. Experiments were conducted in duplicates, with repetition.

Table 3. Enzyme combinations.

\begin{tabular}{cc}
\hline Condition & Enzyme Combinations \\
\hline B1 host & B1 host $10 \mathrm{mg} / \mathrm{g}$ substrate + F10 $40 \mathrm{U} / \mathrm{g}$ substrate \\
B1-XylA & B1-XylA $10 \mathrm{mg} / \mathrm{g}$ substrate + F10 $40 \mathrm{U} / \mathrm{g}$ substrate \\
B1 host + B1-XylA & B1 host $8 \mathrm{mg} / \mathrm{g}$ substrate + B1-XylA $2 \mathrm{mg} / \mathrm{g}$ substrate + F10 $40 \mathrm{U} / \mathrm{g}$ substrate \\
\hline
\end{tabular}

\subsection{Analytical Procedures}

\subsubsection{Glucose Concentration}

Glucose concentration was determined according to the glucose oxidase/peroxidase method [22]. One hundred microliters of solids-free, properly diluted samples were mixed with $1 \mathrm{~mL}$ of the glucose oxidase/peroxidase reagent (R1 + R2 40:1 v/v, from Impact Ltd., Moscow, Russia) and incubated for $15 \mathrm{~min}$ at $40^{\circ} \mathrm{C}$. Absorbance was read at $490 \mathrm{~nm}$ in a UV-vis spectrophotometer (Agilent Technologies Inc., Santa Clara, CA, USA).

\subsubsection{Reducing Sugars Concentration}

The concentration of total reducing sugars was determined according to the Somogyi Nelson method [17-19], using glucose as a standard for calibration. Two hundred microliters of solids-free, properly diluted samples were mixed with $200 \mu \mathrm{L}$ of the Somogyi reagent and incubated for $40 \mathrm{~min}$ at $100{ }^{\circ} \mathrm{C}$. After cooling to room temperature, $200 \mu \mathrm{L}$ of the Nelson reagent were added and incubated for $15 \mathrm{~min}$. Then, $400 \mu \mathrm{L}$ of acetone and $1 \mathrm{~mL}$ of water were added, and the absorbance was measured at $610 \mathrm{~nm}$ in a UV-vis spectrophotometer (Agilent Technologies Inc., Santa Clara, CA, USA).

\subsubsection{High Performance Liquid Chromatography (HPLC) Analysis of Monosaccharides Composition}

The composition of low molecular weight sugars (xylose and fructose) was determined via ion-exchange chromatography on an Agilent 1100 Series HPLC system (Agilent, Santa Clara, CA, USA) with a Diaspher-110-Amin column $5 \mu \mathrm{m} 4 \times 250 \mathrm{~mm}$; the eluent was acetonitrile-water at 75:25 $(v / v)$, the flow rate was $1 \mathrm{~mL} / \mathrm{min}$ and the sample's volume was $10-100 \mu \mathrm{L}$. To prepare samples acetonitrile $(0.8 \mathrm{~mL})$ was added to $0.2 \mathrm{~mL}$ of hydrolysate, followed by centrifugation for $5 \mathrm{~min}$ at 
$9000 \times g$. Solutions of xylose and fructose (Megazyme, Victoria, Australia) at the concentration of $1 \mathrm{~g} / \mathrm{L}$ were used as standards.

\section{Results}

The mass of recovered solids after acid and alkaline pretreatments was determined for each substrate. The concentration of monosaccharides and reducing sugars was also quantified in the liquid fraction of the pretreatment processes, in order to determine the amount of sugars lost in this step. Results are presented in Table 4.

Table 4. Recovery of solids and reducing sugars' loss after acid and alkaline pretreatments.

\begin{tabular}{ccc}
\hline Substrate-Pretreatment & Solids Recovery in Dry Mass Basis (\%) & Sugar Loss in Dry Mass Basis (\%) \\
\hline SCB-Acid & 63.6 & 24.1 \\
SCB-Alkaline & 65.2 & N. d. \\
SBH-Acid & 56.1 & 11.36 \\
SBH-Alkaline & 48.7 & N. d. \\
EFB-Acid & 63.4 & 18.14 \\
EFB-Alkaline & 67.4 & N.d. \\
\hline
\end{tabular}

Note: N. d.—Not detectable; SCB—sugarcane bagasse; SBH—soybean husks; EFB—empty fruit bunches of oil palm.

No detectable amount of sugars was found in the liquid fractions of the alkaline pretreatments in a 1:10 (v/v) dilution, and since the dark color of the liquid interfered in the absorbance reading, it was not possible to test lower dilutions. The acid pretreatment resulted in glucose, xylose and reducing sugars mass losses of $2.71 \%, 20.0 \%$ and $24.1 \%$ in SCB, $0.61 \%, 1.25 \%$ and $11.36 \%$ in SBH and $0.33 \%$, $14.5 \%$ and $18.14 \%$ in EFB, respectively.

The concentrations of total reducing sugars and glucose released along enzymatic saccharification of untreated, acid pretreated and alkaline pretreated substrates are presented in Figures 1-3, respectively.

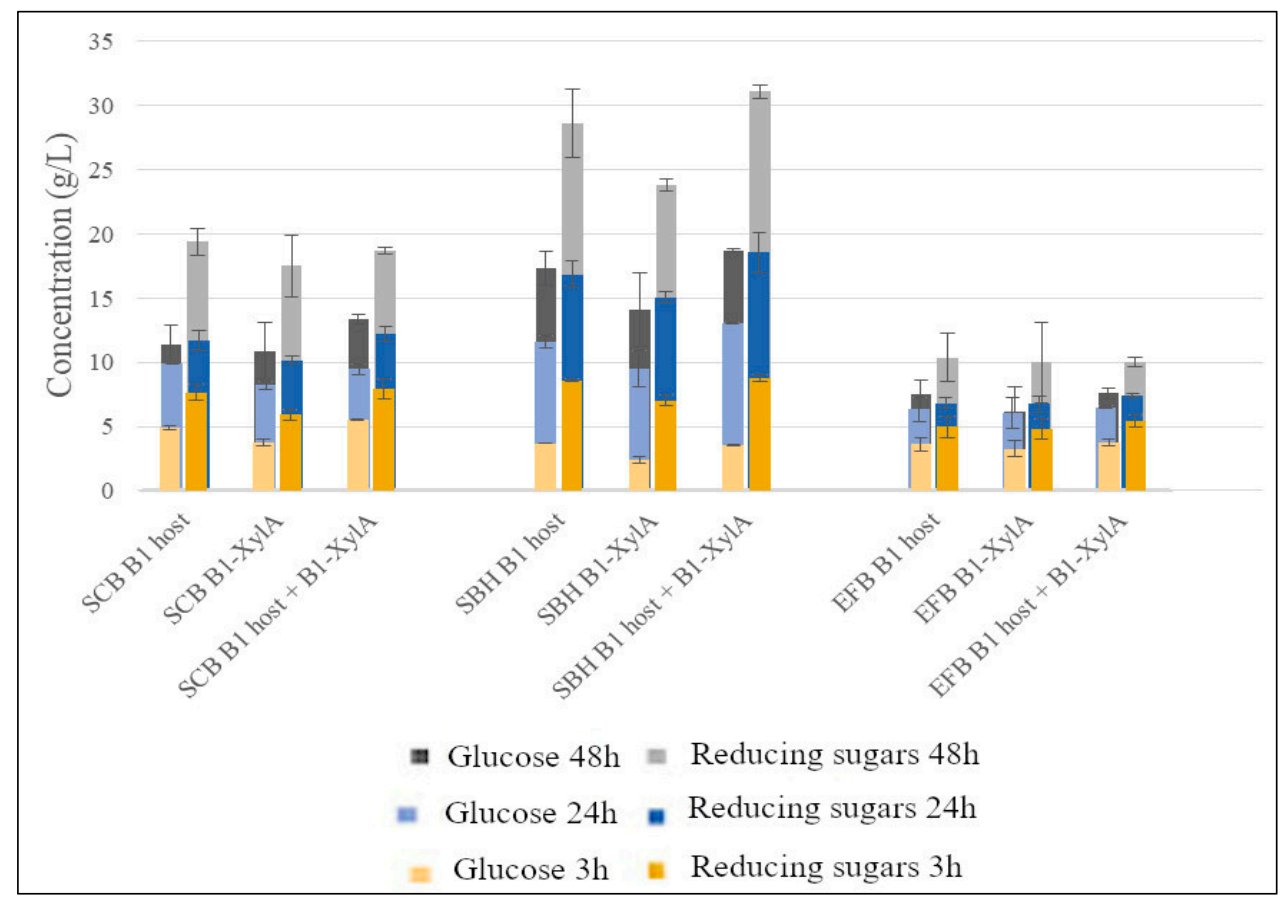

Figure 1. Glucose and reducing sugars released after $3 \mathrm{~h}, 24 \mathrm{~h}$ and $48 \mathrm{~h}$ of enzymatic saccharification of unpretreated sugarcane bagasse (SCB), soybean hulls (SBH) and palm empty fruit bunches (EFB) using different enzyme combinations (B1 host, B1-XylA and B1 host + B1-XylA). 


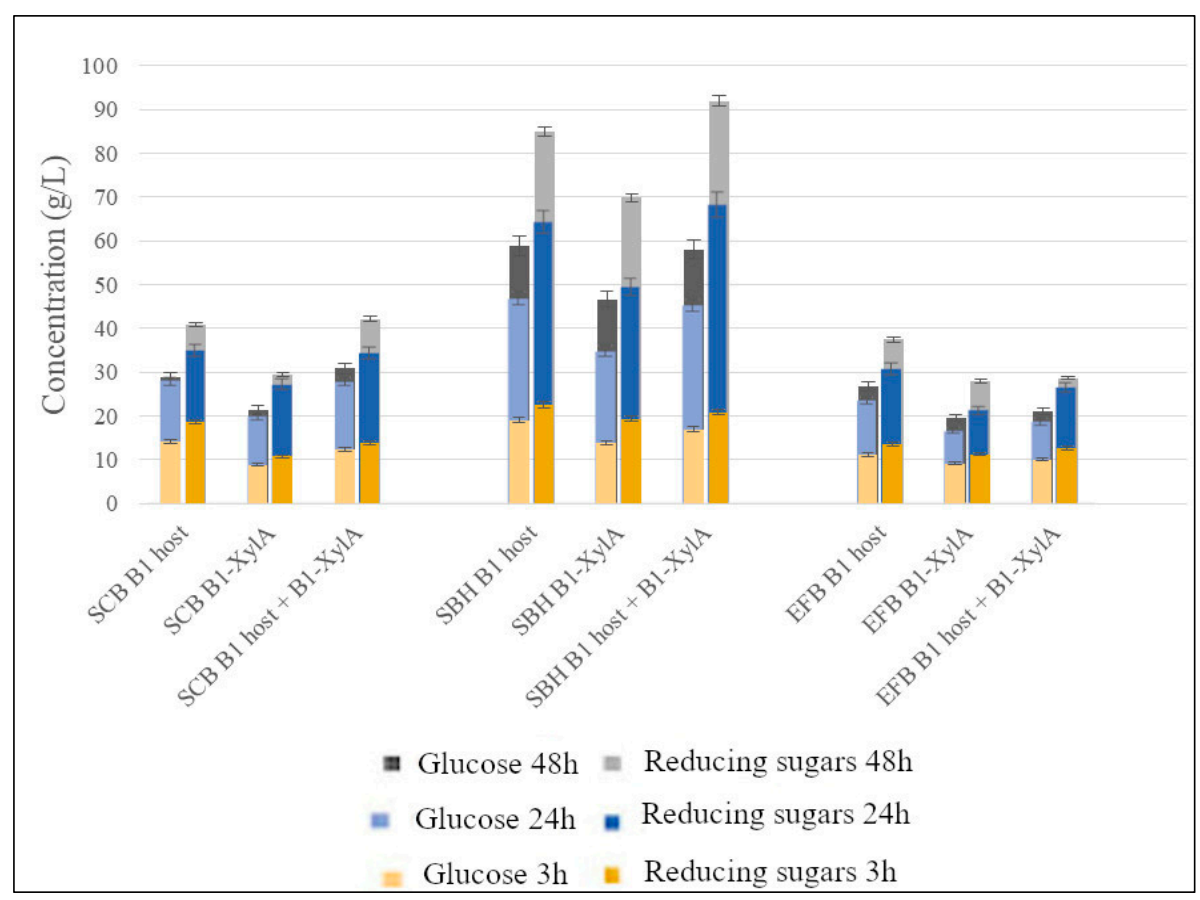

Figure 2. Glucose and reducing sugars released after $3 \mathrm{~h}, 24 \mathrm{~h}$ and $48 \mathrm{~h}$ of enzymatic saccharification of sugarcane bagasse (SCB), soybean hulls (SBH) and palm empty fruit bunches (EFB) after acid pretreatment using different enzyme combinations (B1 host, B1-XylA and B1 host + B1-XylA).

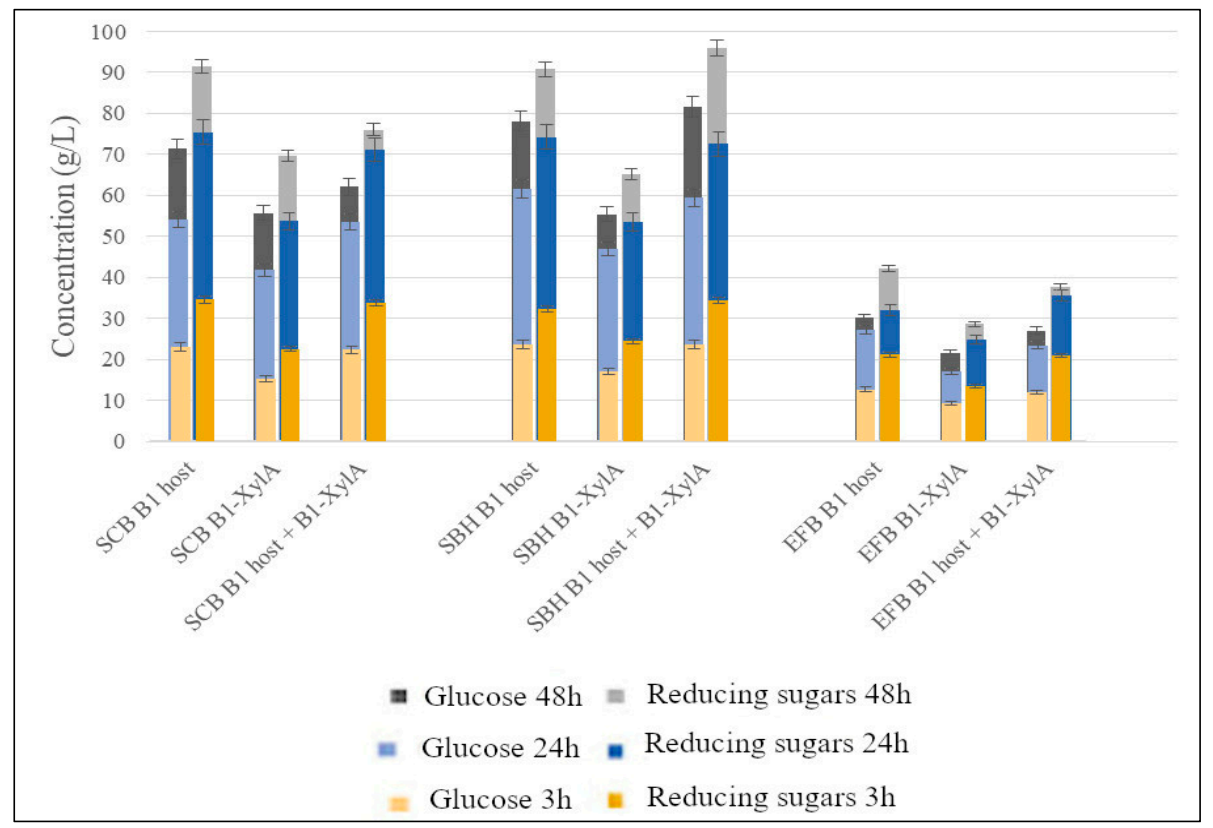

Figure 3. Glucose and reducing sugars released after $3 \mathrm{~h}, 24 \mathrm{~h}$ and $48 \mathrm{~h}$ of enzymatic saccharification of sugarcane bagasse (SCB), soybean hulls (SBH) and palm empty fruit bunches (EFB) after alkaline pretreatment using different enzyme combinations (B1 host, B1-XylA and B1 host + B1-XylA).

Untreated samples of SCB released between 17 and $19 \mathrm{~g} / \mathrm{L}$ of reducing sugars, between 11 and $13 \mathrm{~g} / \mathrm{L}$ of glucose and nearly $2 \mathrm{~g} / \mathrm{L}$ of xylose after $48 \mathrm{~h}$; fructose was not detected. The ratio between glucose and xylose was around 6 , and there was not a significant difference between enzyme preparations. Untreated SBH released, after $48 \mathrm{~h}$, an average of $31 \mathrm{~g} / \mathrm{L}$ of reducing sugars using B1 host + B1-XylA and around $29 \mathrm{~g} / \mathrm{L}$ using B1 host, without significant difference between these enzyme combinations. Glucose concentration, however, was higher with B1 host + B1-XylA (almost 19 g/L). 
Small amounts of xylose and fructose (3-4 g/L of xylose, 2-3 g/L of fructose) were determined with little advantage of B1 host + B1-XylA. Untreated EFB released $10 \mathrm{~g} / \mathrm{L}$ of reducing sugars and around $7.5 \mathrm{~g} / \mathrm{L}$ of glucose after $48 \mathrm{~h}$, using B1 host and B1 host + B1-XylA; when B1-XylA alone was used, the glucose concentration after $48 \mathrm{~h}$ was $6 \mathrm{~g} / \mathrm{L}$. Xylose concentration was of about $3 \mathrm{~g} / \mathrm{L}$ for all enzyme combinations and no fructose was detected.

Mild acid pretreatment was especially efficient in SBH, allowing to obtain $92 \mathrm{~g} / \mathrm{L}$ of reducing sugars after $48 \mathrm{~h}$ when the enzyme combination B1 host + B1-XylA was used. No residual fibers were observed. In $24 \mathrm{~h}, 67 \mathrm{~g} / \mathrm{L}$ of reducing sugars were obtained. Glucose concentration after $48 \mathrm{~h}$ was equivalent between B1 host and B1 host + B1-XylA (58 g/L). These results represent an improvement of $3 \times$ as compared to the untreated samples. Acid pretreated SCB released, after $48 \mathrm{~h}$, around $40 \mathrm{~g} / \mathrm{L}$ of reducing sugars and $30 \mathrm{~g} / \mathrm{L}$ of glucose when using B1 host or B1 host + B1-XylA. In $24 \mathrm{~h}$, concentrations of reducing sugars were in the order of $34 \mathrm{~g} / \mathrm{L}$; thus, no pronounced time-dependent increase was observed. These results represent an improvement of around $2 \times$ and $3 \times$ for reducing sugars and glucose, respectively, as compared to the untreated samples; however, all samples still contained residual fibers after $48 \mathrm{~h}$, indicating that the carbohydrates were not completely accessed. Acid pretreated EFB showed better results for B1 host as compared to other enzyme combinations after $48 \mathrm{~h}$ ( $37 \mathrm{~g} / \mathrm{L}$ of reducing sugars and $27 \mathrm{~g} / \mathrm{L}$ of glucose), an improvement of $3.7 \times$ as compared to untreated samples. Similar to SCB, residual fibers were observed after $48 \mathrm{~h}$ of hydrolysis.

Alkaline pretreatment was the most effective for $\mathrm{SCB}$, and the enzyme preparation $\mathrm{B} 1$ host was the most efficient among all. Concentrations of $91 \mathrm{~g} / \mathrm{L}$ reducing sugars and $71 \mathrm{~g} / \mathrm{L}$ glucose were obtained after $48 \mathrm{~h}$. After $24 \mathrm{~h}$, concentrations were $75 \mathrm{~g} / \mathrm{L}$ and $54 \mathrm{~g} / \mathrm{L}$, respectively. This represents an improvement of $5 \times$ and $6 \times$ in relation to untreated samples and of around $2 \times$ in relation to acid pretreated samples. Alkaline pretreated SBH released $96 \mathrm{~g} / \mathrm{L}$ of reducing sugars and $81 \mathrm{~g} / \mathrm{L}$ of glucose, after $48 \mathrm{~h}$, when using the enzyme preparation B1 host + B1-XylA. This preparation also provided the best results in acid-pretreated samples of SBH. In $24 \mathrm{~h}$, enzyme preparations B1 host and B1 host + B1-XylA released around $73 \mathrm{~g} / \mathrm{L}$ of reducing sugars and around $60 \mathrm{~g} / \mathrm{L}$ of glucose. When comparing mild acid and alkaline pretreatments for $\mathrm{SBH}$, a slight increase was observed for reducing sugars, from 92 to $96 \mathrm{~g} / \mathrm{L}$, and an important increase was observed for glucose, from 58 to $81 \mathrm{~g} / \mathrm{L}$. Alkaline pretreated EFB samples released $42 \mathrm{~g} / \mathrm{L}$ of reducing sugars and $30 \mathrm{~g} / \mathrm{L}$ of glucose after $48 \mathrm{~h}$, when using B1 host. These results are consistent with those obtained for acid pretreated EFB, indicating a similar effect of both pretreatments and a better effect of the enzyme preparation B1 host in this substrate. However, it is clear that the potential of the substrate was not fully accessed yet. It is important to remark that, between 24 and $48 \mathrm{~h}$ of enzymatic hydrolysis, alkaline pretreated sugarcane bagasse and soybean husks were completely liquefied, while empty fruit bunches remained in great part as a solid fraction after $48 \mathrm{~h}$ of hydrolysis.

Table 5 presents the summary of the best saccharification results obtained for each substrate and pretreatment, and the corresponding enzyme combinations.

Table 5. Summary of best results of enzymatic saccharification after $48 \mathrm{~h}$.

\begin{tabular}{|c|c|c|c|c|c|}
\hline $\begin{array}{c}\text { Substrate- } \\
\text { Pretreatment }\end{array}$ & Enzyme Combination & $\begin{array}{c}\text { Glucose } \\
\text { Concentration } \\
(\mathrm{g} / \mathrm{L})\end{array}$ & $\begin{array}{c}\text { Reducing Sugars } \\
\text { Concentration } \\
(\mathrm{g} / \mathrm{L})\end{array}$ & $\begin{array}{c}\text { Glucose } \\
\text { Yield (g/100 g } \\
\text { Substrate) }\end{array}$ & $\begin{array}{l}\text { Reducing Sugars } \\
\text { Yield (g/100 g } \\
\text { Substrate) }\end{array}$ \\
\hline SCB-Untreated & B1 host, B1-XylA or B1 host + B1-XylA & 12 & 18 & 11 & 16 \\
\hline SCB-Acid & B1 host or B1 host + B1-XylA & 30 & 40 & $17(27)$ & $23(36)$ \\
\hline SCB_Alkaline & B1 host & 71 & 91 & $42(65)$ & $54(83)$ \\
\hline SBH-Untreated & B1 host + B1-XylA & 19 & 31 & 17 & 28 \\
\hline SBH-Acid & B1 host + B1-XylA & 58 & 92 & $30(53)$ & $47(84)$ \\
\hline SBH_Alkaline & B1 host + B1-XylA & 81 & 96 & $36(74)$ & $42(87)$ \\
\hline EFB-Untreated & $\mathrm{B} 1$ host or B1 host + B1-XylA & 7.5 & 10 & 6.8 & 9 \\
\hline EFB-Acid & B1 host & 27 & 37 & $16(25)$ & $21(34)$ \\
\hline EFB_-Alkaline & B1 host & 30 & 42 & $18(27)$ & $26(38)$ \\
\hline
\end{tabular}

Note: The yields of glucose and reducing sugars were calculated based on the total initial mass of dry substrates (before pretreatment); values in parentheses represent the yields obtained from the mass recovered after pretreatment, in dry basis; it was considered that, after enzymatic hydrolysis, one molecule of water is incorporated in each monomer. SCB—sugarcane bagasse; SBH—soybean husks; EFB—empty fruit bunches of oil palm. 


\section{Discussion}

The association of efficient enzyme cocktails and effective pretreatment strategies has a very important function in making the saccharification of lignocellulosic biomass feasible, especially of the most recalcitrant biomass types. Sugarcane bagasse and palm empty fruit bunches are very fibrous materials, while soybean husks are softer and easier to grind. SCB is porous and absorbs water in approximately 10 times its mass, while palm EFB is harder and less porous. These characteristics were reflected in the efficiency of pretreatments and saccharification.

SBH was easily hydrolyzed after both acid and alkaline pretreatments, and even the untreated SBH samples released a considerable amount of reducing sugars (around $30 \mathrm{~g} / \mathrm{L}$ ). On the other hand, EFB was the most recalcitrant substrate, with no difference between acid and alkaline pretreatments in terms of reducing sugars yield. Sugarcane bagasse was the substrate that showed the most pronounced effect of pretreatment type, being the alkaline pretreatment significantly more effective than the acid one. This is probably related to the ability of alkali to solubilize lignin, which was successfully achieved considering the porous nature of SCB.

Acid pretreatment is highly effective in disrupting the lignocellulosic matrix by the cleavage of glycosidic bonds. This process mainly solubilizes the hemicellulosic portion of the biomass, and part of the lignin [23]. Alkaline pretreatment removes lignin with high efficiency and cleaves glycosidic and ester side chains, contributing to decrystallization, increased porosity and swelling of cellulose [2]. These modifications facilitate in great extent the access of enzymes to the carbohydrate molecules. An approach to take advantage of both mechanisms is the sequential acid-alkaline pretreatment. This strategy has been applied to corn stover and corn cobs resulting in reducing sugar yields higher than $90 \%$ [23]. However, the need to perform two separate steps of thermochemical treatments increases process costs and time, discouraging the application in an industrial scale.

In our experiments, sugar losses between 11 and $24 \%$ were detected after acid pretreatment, as presented in Table 4. Alkaline pretreatment was more selective to lignin, as observed from the brown color of the resulting liquid phase. Regardless of the pretreatment strategy, there were significant mass losses for all substrates, which were in the order of $32-37 \%$ for SCB and EFB. SBH was the substrate that presented the most pronounced mass loss as a result of pretreatment, either acid $(43.9 \%)$ or alkaline $(51.3 \%)$. Considering the low lignin content of this substrate, we assumed that one of the factors contributing to this mass loss was the small particle size of the grinded material. Although all substrates were grinded and particle sizes $<3 \mathrm{~mm}$ were selected, SCB and EFB presented a small-fibers aspect after mechanical processing and selection, while SBH presented a powder aspect. Another point to be considered is the relatively high concentration of proteins (14\%, Table 1$)$ that can be extracted by the thermochemical pretreatments. Rojas et al. [24] reported a mass yield of $40 \%$ after acid pretreatment of SBH with $\mathrm{H}_{2} \mathrm{SO}_{4} 3 \%(v / \mathrm{v}), 25 \%$ of solids, at $120{ }^{\circ} \mathrm{C}$ for $40 \mathrm{~min}$, and this mass loss of $60 \%$ was mainly attributed to the solubilization of protein, pectin and hemicellulose. The high solubilization of biomass components and the possible loss of small particles during pretreatment in the present work contributed to the relatively low yields of reducing sugars recovery from the initial mass of SBH $(42-47 \%$, Table 5), despite the high efficiency of enzymatic hydrolysis.

The enzymatic saccharification of sugarcane bagasse has been widely studied in the last decade. Today, sugarcane bagasse is the second most important agro-industrial residue used as a feedstock for $2 \mathrm{G}$ ethanol, after corn residues. Even so, the scientific literature still reports challenges to be overcome in the conversion of substrates and sugar release, especially when considering industrial applications. Prajapati et al. [2] applied a cocktail of cellulases and hemicellulases from A. tubingensis to hydrolyze alkali treated sugarcane bagasse, with $6-8 \%(w / v)$ solids, for $96 \mathrm{~h}$ at $45{ }^{\circ} \mathrm{C}$, applying an enzyme preparation containing FPase activity $(1.03 \mathrm{U} / \mathrm{mL}), \beta$-glucosidase $(0.6 \mathrm{U} / \mathrm{mL})$, endo- $\beta$-glucanase $(6.8 \mathrm{U} / \mathrm{mL}), \alpha$-galactosidase $(1.6 \mathrm{U} / \mathrm{mL}), \beta$-xylosidase $(0.17 \mathrm{U} / \mathrm{mL}), \beta$-mannosidase $(0.05 \mathrm{U} / \mathrm{mL})$, endo- $\beta$-mannanase $(13.7 \mathrm{U} / \mathrm{mL})$ and endo- $\beta$-xylanase $(7.26 \mathrm{U} / \mathrm{mL})$. The maximum concentration of released sugars was around $20 \mathrm{~g} / \mathrm{L}$ of a mixture of glucose, xylose and arabinose. Scarpa et al. [25] reached a glucose concentration of $7.32 \mathrm{~g} / \mathrm{L}$ from sugarcane bagasse submitted to hydrothermal alkaline 
pretreatment, at a solids load of $13.5 \%$ ( $w / v$, dry basis) and an endoglucanase load of $288 \mathrm{U} / \mathrm{g}$ cellulose, for $130 \mathrm{~h}$ and $57^{\circ} \mathrm{C}$. These are considered low concentrations for industrial fermentations, especially in the segment of bioethanol production.

Martin et al. [26] evaluated the saccharification of sugarcane bagasse pretreated with a mixture of glycerol and sulfuric acid $\left(79.6 \%\right.$ glycerol, 0.6 or $\left.1.1 \% \mathrm{H}_{2} \mathrm{SO}_{4}\right)$ or with sulfuric acid alone $\left(1.1 \% \mathrm{H}_{2} \mathrm{SO}_{4}\right)$, at $188-194{ }^{\circ} \mathrm{C}$, for $100-140 \mathrm{~min}$. The authors also evaluated six enzyme preparations, three commercial Trichoderma-based cocktails and three preparations developed at the Bach Institute of Biochemistry (Russian Academy of Sciences), namely PV (host strain cellulase/xylanase cocktail—the same B1 host preparation used in our experiments), PV-Xyl PCA (produced by a recombinant $P$. verruculosum strain after heterologous expression of P. canescens xylanase A), and PV-Hist BGL (produced by a recombinant P. verruculosum strain after heterologous expression of $A$. niger $\beta$-glucosidase). Both PV-Xyl and PV-Hist BGL preparations also contained the cellulase complex of $P$. verruculosum. Better results of enzymatic convertibility were obtained with glycerol-treated bagasse. After $48 \mathrm{~h}$ of hydrolysis, around $30 \mathrm{~g} / \mathrm{L}$ of reducing sugars, mostly represented by glucose, were obtained (using the PV enzyme loading of $10 \mathrm{mg}$ protein/g substrate and $50 \mathrm{~g} / \mathrm{L}$ of substrate), corresponding to a cellulose conversion value of almost $80 \%$. The preparation PV-Xyl is the same as the B1-XylA preparation used in our experiments. It has already been tested for bagasse, aspen and pine wood and results were reported by Osipov et al. [15]. These results corroborate the suitability of the enzyme cocktails obtained from P. verruculosum to hydrolyze sugarcane bagasse. Since these cocktails are crude preparations, the economic feasibility of the process can be significantly enhanced as compared to the use of commercial purified preparations.

Hickert et al. [27] performed the saccharification of soybean husks using an enzyme preparation obtained from Penicillium echinulatum. Pretreatment was performed by dilute acid hydrolysis $\left(121^{\circ} \mathrm{C}\right.$, $40 \mathrm{~min}$, solid-liquid ratio of 1:10,1\% v/v sulphuric acid) and it was followed by enzymatic hydrolysis using a solid-liquid proportion of 1:20 (dry matter in citrate phosphate buffer $\mathrm{pH} 4.8$ ), P. echinulatum S1M29 enzyme preparation (enzyme loading of 10, 15, or $20 \mathrm{FPU} / \mathrm{g}$ ), at $120 \mathrm{rpm}, 50{ }^{\circ} \mathrm{C}$ for $96 \mathrm{~h}$. The liquid fractions of acid pretreatment and enzymatic hydrolysis were mixed, yielding a solution containing (g/L): glucose 38 , xylose 21 , arabinose 4 , mannose 6 and cellobiose 7 . The efficiency of saccharification was $72 \%$. Qing et al. [28] studied the saccharification of SBH submitted to acid and alkaline pretreatments $\left(1 \% v / v \mathrm{H}_{2} \mathrm{SO}_{4}\right.$ or $\left.\mathrm{NaOH}, 120^{\circ} \mathrm{C}, 1 \mathrm{~h}\right)$ using the commercial preparation Accelerase 1500 (60 FPU/g), and results were different from those of the present work, since the alkaline pretreatment promoted considerably higher enzymatic conversion than the acid one $(80 \%$ versus $65 \%$ ). There are no literature reports on the application of the enzyme preparations obtained from P. verruculosum, used in the present work, to hydrolyze SBH or EFB.

The saccharification of oil palm EFB was evaluated by Medina et al. [12], comparing acid-alkaline pretreatment, steam explosion and steam explosion with alkaline delignification. The enzymatic digestibility of the pretreated substrate was evaluated with Celluclast ${ }^{\circledR} 1.5 \mathrm{~L}$ and Novozym 188 (mass ratio of 1:0.3), loaded at $60 \mathrm{FPU}$ per $\mathrm{g} \mathrm{EFB}$, with $\mathrm{pH} 4.8$ (0.1 M sodium citrate buffer) and maintained at $55^{\circ} \mathrm{C}, 130 \mathrm{rpm}$ for 5 days. The mass-volume ratio of EFB was $2.5 \%(w / v)$. The best result of enzymatic digestibility ( $72 \%$ after 5 days) was obtained with the sequential acid-alkaline pretreatment $\left(1 \% \mathrm{H}_{2} \mathrm{SO}_{4}\right.$, $2.5 \% \mathrm{NaOH}, 121^{\circ} \mathrm{C}$ ), while digestibility results obtained with steam explosion coupled with alkaline delignification were lower than $50 \%$, and with steam explosion alone, lower than $16 \%$. These results, together with the findings of the present research, indicate that the recalcitrant nature of EFB cannot be overcome by traditional industrial pretreatment methods such as steam explosion and single-step thermochemical pretreatments, and that both pretreatment and saccharification are bottlenecks to be optimized for this substrate.

\section{Conclusions}

The effects of different enzyme combinations were demonstrated in the saccharification of sugarcane bagasse, soybean husks and oil palm empty fruit bunches submitted to mild acid and alkaline pretreatments. Sugarcane bagasse was efficiently saccharified after alkaline pretreatment, 
while soybean husks were efficiently saccharified regardless of the pretreatment method. Palm empty fruit bunches also showed similar responses of enzymatic saccharification independently of the pretreatment strategy; however, with much lower sugar yields. The best enzyme choice for sugarcane bagasse was B1 host, representing a cellulase/xylanase complex of $P$. verruculosum; for soybean husks, the combination of B1 host $(80 \%)$ and B1-XylA $(20 \%)$, this last one obtained through the recombinant expression of P. canescens xylanase A in the P. verruculosum B1 host strain, gave the best results; for palm empty fruit bunches, the B1 host preparation was the most efficient.

Author Contributions: Conceptualization, C.R.S. and A.P.S.; methodology, D.O.O., I.N.Z. and O.A.S.; validation, S.G.K.; formal analysis, D.O.O. and I.N.Z.; investigation, S.G.K. and M.V.S.; data curation, D.O.O., M.V.S. and O.A.S.; writing—original draft preparation, S.G.K.; writing—review and editing, A.M.R. and C.R.S.; supervision, A.P.S.; project administration, A.M.R. and C.R.S. All authors have read and agreed to the published version of the manuscript.

Funding: This research was funded in part by the Coordenação de Aperfeiçoamento de Pessoal de Nível Superior-Brasil (CAPES)-Finance code 88887.472495/2019-00, in the frame of the project Biotechnology Processes for the Production of Advanced Biofuels (BioADD), CAPES-PRINT UFPR, and in part by the Russian Foundation for Basic Research (RFBR No. 18-54-80027). The APC was funded by the Russian Foundation for Basic Research (RFBR No. 18-54-80027).

Acknowledgments: Authors are thankful to Julio César de Carvalho, Luciana Porto de Souza Vandenberghe, Adenise Lorenci Woiciechowski and Luiz Alberto Júnior Letti for administrative and technical support, and to the companies Biopalma Vale S.A., Usina Santa Terezinha and Imcopa for providing the substrates.

Conflicts of Interest: The authors declare no conflict of interest. The funders had no role in the design of the study; in the collection, analyses, or interpretation of data; in the writing of the manuscript, or in the decision to publish the results.

\section{References}

1. Magalhães, A.I. Jr.; Carvalho, J.C.; Pereira, G.V.M.; Karp, S.G.; Câmara, M.C.; Medina, J.D.C.; Soccol, C.R. Lignocellulosic biomass from agro-industrial residues in South America: Current developments and perspectives. Biofuels Bioprod. Bioref. 2019, 13, 1505-1519. [CrossRef]

2. Prajapati, B.P.; Jana, U.K.; Suryawanshi, R.K.; Kango, N. Sugarcane bagasse saccharification using Aspergillus tubingensis enzymatic cocktail for 2G bio-ethanol production. Renew. Energ. 2020, 152, 653-663. [CrossRef]

3. Karp, S.G.; Woiciechowski, A.L.; Soccol, V.T.; Soccol, C.R. Pretreatment strategies for delignification of sugarcane bagasse: A review. Braz. Arch. Biol. Technol. 2013, 56, 679-689. [CrossRef]

4. FAO-Food and Agriculture Organization of the United Nations. FAOSTAT Crops. Available online: http://www.fao.org/faostat/en/\#data/QC (accessed on 10 May 2020).

5. USDA-United States Department of Agriculture. Sugar: World Markets and Trade. Available online: https://apps.fas.usda.gov/psdonline/circulars/sugar.pdf (accessed on 10 May 2020).

6. CONAB-Companhia Nacional de Abastecimento. Safra Brasileira de Cana de Açúcar. Available online: https://www.conab.gov.br/info-agro/safras/cana (accessed on 10 May 2020).

7. Rodrigues, R.C.L.B.; Felipe, M.G.A.; Sil, J.B.A.; Vitolo, M. Response surface methodology for xylitol production from sugarcane bagasse hemicellulosic hydrolyzate using controlled vacuum evaporation process variables. Proc. Biochem. 2003, 38, 1231-1237. [CrossRef]

8. Soccol, C.R.; Vandenberghe, L.P.S.; Medeiros, A.B.P.; Karp, S.G.; Buckeridge, M.; Ramos, L.P.; Pitarelo, A.P.; Ferreira-Leitão, V.; Gottschalk, L.M.F.; Ferrara, M.A.; et al. Bioethanol from lignocelluloses: Status and perspectives in Brazil. Bioresour. Technol. 2010, 101, 4820-4825. [CrossRef]

9. USDA-United States Department of Agriculture. World Agricultural Production. Available online: https://apps.fas.usda.gov/psdonline/circulars/production.pdf (accessed on 10 May 2020).

10. Karp, S.G.; Igashiyama, A.H.; Siqueira, P.F.; Carvalho, J.C.; Vandenberghe, L.P.S.; Thomaz-Soccol, V.; Coral, J.; Tholozan, J.L.; Pandey, A.; Soccol, C.R.; et al. Application of the biorefinery concept to produce L-lactic acid from the soybean vinasse at laboratory and pilot scale. Bioresour. Technol. 2011, 102, 1765-1772. [CrossRef]

11. Liu, H.-M.; Li, H.-Y. Application and conversion of soybean hulls. In Soybean-The Basis of Yield, Biomass and Productivity, 1st ed.; Kasai, M., Ed.; IntechOpen: London, UK, 2017. [CrossRef] 
12. Medina, J.D.C.; Woiciechowski, A.L.; Zandona Filho, A.; Brar, S.K.; Magalhães Júnior, A.I.; Soccol, C.R. Energetic and economic analysis of ethanol, xylitol and lignin production using oil palm empty fruit bunches from a Brazilian factory. J. Clean. Prod. 2018, 195, 44-55. [CrossRef]

13. Morozova, V.V.; Gusakov, A.V.; Andrianov, R.M.; Pravilnikov, A.G.; Osipov, D.O.; Sinitsyn, A.P. Cellulase complex of the fungus Penicillium verruculosum: Properties of major endoglucanases and cellobiohydrolases. Biotechnol. J. 2010, 5, 871-880. [CrossRef]

14. Gusakov, A.V.; Sinitsyn, A.P. Cellulases from Penicillium species for producing fuel from biomass. Biofuels 2012, 3, 463-477. [CrossRef]

15. Osipov, D.O.; Rozhkova, A.M.; Matys, V.Y.; Koshelev, A.V.; Okunev, O.N.; Rubtsova, E.A.; Pravilnikov, A.G.; Zorov, I.N.; Oveshnikov, I.N.; Davidov, E.R.; et al. Production of biocatalysts on the basis of recombinant heterologous xylanase producer strains in the Penicillium verruculosum fungus: Their application in the hydrolysis of timber and wood processing industry wastes. Catal. Ind. 2011, 3, 34-40. [CrossRef]

16. Dotsenko, G.S.; Gusakov, A.V.; Rozhkova, A.M.; Korotkova, O.G.; Sinitsyn, A.P. Heterologous beta-glucosidase in a fungal cellulase system: Comparison of different methods for development of multienzyme cocktails. Proc. Biochem. 2015, 50, 1258-1263. [CrossRef]

17. Nelson, N. A photometric adaptation of the Somogyi method for the determination of sugars. J. Biol. Chem. 1944, 153, 375-379.

18. Somogyi, M. A new reagent for the determination of sugars. J. Biol. Chem. 1945, 160, 61-68.

19. Somogyi, M. Notes on sugar determination. J. Biol. Chem. 1952, 195, 19-23.

20. Sinitsyna, O.A.; Bukhtoyarov, E.F.; Gusakov, A.V.; Okunev, O.N.; Bekkarevitch, A.O.; Vinetsky, Y.P.; Sinitsyn, A.P. Isolation and properties of major components of Penicillium canescens extracellular enzyme complex. Biochemistry 2003, 68, 1200-1209. [CrossRef] [PubMed]

21. Bulakhov, A.G.; Volkov, P.V.; Rozhkova, A.M.; Gusakov, A.V.; Nemashkalov, V.A.; Sinitsyn, A.P. Using an inducible promoter of a gene encoding Penicillium verruculosum glucoamylase for production of enzyme preparations with enhanced cellulase performance. PLoS ONE 2017, 12, e0170404. [CrossRef]

22. Kaputska, L.A.; Annala, A.E.; Swanson, W.C. The peroxidase-glucose oxidase system: A new method to determine glucose liberated by carbohydrate degrading soil enzymes. Plant Soil 1981, 63, 487-490. [CrossRef]

23. Woiciechowski, A.L.; Dalmas Neto, C.J.; Vandenberghe, L.P.S.; Carvalho Neto, D.P.; Sydney, A.C.N.; Letti, L.A.J.; Karp, S.G.; Torres, L.A.Z.; Soccol, C.R. Lignocellulosic biomass: Acid and alkaline pretreatments and their effects on biomass recalcitrance-Conventional processing and recent advances. Bioresour. Technol. 2020, 304, 122848. [CrossRef]

24. Rojas, M.J.; Siqueira, P.F.; Miranda, L.C.; Tardioli, P.W.; Giordano, R.L.C. Sequential proteolysis and cellulolytic hydrolysis of soybean hulls for oligopeptides and ethanol production. Ind. Crop. Prod. 2014, 61, 202-210. [CrossRef]

25. Scarpa, J.C.P.; Marques, N.P.; Monteiro, D.A.; Martins, G.M.; de Paula, A.V.; Boscolo, M.; Silva, R.; Gomes, E.; Bocchini, D.A. Saccharification of pretreated sugarcane bagasse using enzymes solution from Pycnoporus sanguineus MCA 16 and cellulosic ethanol production. Ind. Crop. Prod. 2019, 111795. [CrossRef]

26. Martin, C.; Volkov, P.V.; Rozhkova, A.M.; Puls, J.; Sinitsyn, A.P. Comparative study of the enzymatic convertibility of glycerol- and dilute acid-pretreated sugarcane bagasse using Penicillium-and Trichoderma-based cellulase preparations. Ind. Crop. Prod. 2015, 77, 382-390. [CrossRef]

27. Hickert, L.R.; Cruz, M.M.; Dillon, A.J.P.; Fontana, R.C.; Rosa, C.A.; Ayub, M.A.Z. Fermentation kinetics of acid-enzymatic soybean hull hydrolysate in immobilized-cell bioreactors of Saccharomyces cerevisiae, Candida shehatae, Spathaspora arborariae, and their co-cultivations. Biochem. Eng. J. 2014, 88, 61-67. [CrossRef]

28. Qing, Q.; Guo, Q.; Zhou, L.; Gao, X.; Lu, X.; Zhang, Y. Comparison of alkaline and acid pretreatments for enzymatic hydrolysis of soybean hull and soybean straw to produce fermentable sugars. Ind. Crop. Prod. 2017, 109, 391-397. [CrossRef]

(C) 2020 by the authors. Licensee MDPI, Basel, Switzerland. This article is an open access article distributed under the terms and conditions of the Creative Commons Attribution (CC BY) license (http://creativecommons.org/licenses/by/4.0/). 